\title{
TALOUDEN IHMETTELYÄ?
}

Ilkka Niiniluoto, Risto Vilkko \& Jaakko Kuorikoski (toim.): Talous ja filosofia. Helsinki: Gaudeamus 2013.

Suomen filosofinen yhdistys järjestää vuosittain tammikuisen "yhden sanan" kollokvion. Vuonna 2012 kollokvion aiheena oli talous. Aihe kokosi yhteen suurehkon joukon lähinnä tiedeyhteisössä paikkansa vakiinnuttaneita filosofeja. Mukaan mahtui myös sosiologeja ja talouden ammattilaisia. Gaudeamuksen julkaisema Talous ja filosofia on kokoelma tässä kollokviossa pidettyjä esitelmiä. Koska kirjan aihepiirit ja lähestymistavat vaihtelevat laajasti, voidaan kirjaa pitää eräänlaisena kokoelmana filosofien puheenvuoroja taloudesta. Suurin osa teksteistä ei käsittele siis talouden ja filosofian suhdetta - mikä olisikin ollut paljon kunnianhimoisempi filosofinen projekti.

Talous ja politiikka on ulkoisesti hyvin toimitettu teos. Kaikki tekstit ovat muodollisesti laadukkaita ja pituudeltaan jokseenkin yhtäläisiä. Kieltä on huollettu runsaasti, ehkäpä jossain kohdissa liikaakin: teksti muistuttaa välillä enemmän Yleisradion selkouutisia kuin tieteellistä tekstiä, jossa kaikki asiat eivät aina taivu aivan yleistajuiseen ja yksinkertaiseen muotoon. Kirjan toimittamisessa on valittu tiedettä popularisoiva linja. Yhdeksi teoksen yleiseksi ongelmaksi muodostuukin tekstien tieteellinen pätevyys. Kaikki tekstit on kirjoitettu ilman lähdeviitteitä, mikä tekee joidenkin tekstien arvioinnista hankalaa. Tässä mielessä lukija on kirjoittajan sanan ja auktoriteetin varassa. Viitataanpa yhdessä tekstissä jopa kuulopuheisiin, minkä olisi hyvin voinut jättää tämän tyyppisestä tekstistä pois (s. 104). Artikkelien loppuun on liitetty lyhyet lisälukemista-osiot, jotka antavat lukijalle osviittaa siitä, mistä lisätietoa kannattaa etsiä. Valitettavasti kirjan toimituspolitiikkana on ollut suositella vain suomen- ja englanninkielistä kirjallisuutta. Laadukasta talousfilosofista ajattelua kirjoitetaan toki ympäri maailmaa.

Yleisesti kirjan orientaatiosta voidaan mainita vielä se, että kirjoittajakunta koostuu pääasiassa analyyttisen filosofian ammattilaisista. Tämä johtunee paljolti Suomen filosofisen yhdistyksen järjestämän kollokvion esiintyjäkaartista. Jos kirja ei olisi alustusten pohjalta koottu puheenvuoro- ja katsauskirja, olisi tätä orientaatiota syytä kritisoida liian suppeasta lähestymistavasta. Kun taloutta tarkastellaan pääasiassa vain anglo-amerikkalaisesta analyyttisestä perspektiivistä, jää ulos useita varsin mielenkiintoisia ja hedelmällisiä lähestymistapoja. Nyt ainoastaan Jussi Kotkavirran ja Eerik Lagerspetzin artikkelit tarjoavat hieman toisenlaista näkökulmaa. Tämä on ilmiselvä puute, varsinkin suhteessa kirjan nimen yleisyyteen.

\section{TALOUDEN FILOSOFINEN KYSYMYS}

Toimittajien kirjoittama johdanto lähtee liikkeelle kysymällä, miksi myös filosofit alkavat kirjoittaa taloudesta aikakaudella, jolloin taloudesta ja rahasta on tullut median suosikkiaiheita. Toimittajat kysyvät: "Eikö heiltä [filosofeilta] toivota henkeviä puheenvuoroja, joissa käsitellään ja painotetaan aivan toisia arvoja, kuten totuutta, kauneutta ja hyvyyttä” (s. 7). Kaikki kirjat täytyy aloittaa jollain tavalla, mutta tästä retorisesta avauksesta kirja saa omituisen sävyn. Syntyy nimittäin vaikutelma, että ikään kuin talous ja kaikki siihen liittyvä - siis työ, tuotanto, vaihto, markkinat, raha jne. - ei itsestään selvästi kuuluisi 
filosofian alaan tai ikään kuin talouden tarkastelu filosofisesti olisi jotenkin poikkeuksellista.

Vaikka kirja korjaakin heti kurssiaan esittämällä lyhyen ja siksi varsin yleisluontoisen katsauksen filosofian historiassa käytyihin talouskeskusteluihin, jää alkuasetelma vaivaamaan lukijaa. Etenkin poliittisen ajattelun historian näkökulmasta katsottuna kun talous on ollut aina tavalla tai toisella yhteiskuntafilosofian keskiössä. Yhteiskuntafilosofian historiassa on varmasti huomattavasti vähemmän niitä filosofeja, jotka eivät ole kirjoittaneet taloudesta kuin niitä, jotka ovat siitä kirjoittaneet. Tietenkin on myös erikoista asettaa raha "arvoksi" kauneuden ja hyvyyden rinnalle. Jollain tavalla kirja lähtee siis liikkeelle ajatuksesta, jonka mukaan on poikkeuksellista tarkastella taloutta filosofisesti. Historiallisesta näkökulmasta katsottuna tämä johtunee kuitenkin enemmän 1900-luvun tieteiden jakautumisesta ja filosofian marginalisoitumisesta, kuin talouden kysymyksen vieraudesta filosofiselle ajattelulle.

Lyhyen ja hyppivän filosofian ja talouden historiallisia suhteita esittelevän katsauksen jälkeen johdanto esittelee lyhyesti "Talouden filosofian peruskysymyksiä". Valitettavasti tämäkin osio jää pintapuoliseksi ja kevyeksi, sillä neljän sivun tekstistä kolme menee kirjaan valittujen artikkeleiden esittelyyn. Vaikka monet kirjan tekstit käsittelevät talouden filosofian peruskysymyksiä, on alaluvun otsikko kuitenkin harhaanjohtava. Näin ollen kirjan määritelmäksi talouden filosofiasta kiteytyy seuraava virke: "Talouden filosofia on usein analyyttista tarkastelua, joka paljastaa taloudellisen ajattelun ja toiminnan taustalla olevia kätkettyjä oletuksia” (s. 12). Kokemattomampi lukija voisi tästä virkkeestä olettaa, että filosofia tutkii noin yleisestikin "taustalla olevia kätkettyjä oletuksia”.

Talouden filosofiasta ei johdannossa sanota tämän enempää, mutta sen sijaan kirjoittajat tekevät terminologisen hyppäyksen erityisesti taloustieteen filosofiaan. Heidän mukaansa se tarkastelee taloustieteen metodologisia oletuksia ja eettisiä linjauksia. Se myös pohtii, miten "talouden toiminnasta voidaan parhaiten tuottaa tietoa ja miten taloudellista toimintaa tulisi tieteellisesti ymmärtää” (s. 12.) Taloustieteen filosofia on läheisessä suhteessa tieteenfilosofiaan, ja siksi se"pyrkii selventämään ehtoja,joiden nojalla epätosia oletuksia sisältävät teoriat ja mallit voivat paljastaa totuuksia taloudesta” (s. 13).

Lukija ei siis oikeastaan saa kirjan johdannosta selkeää kuvaa siitä, mitkä ovat talouden filosofian peruskysymykset. Vaikuttaa siltä, että filosofia ymmärretään "totuutta” etsivänä ja selvittävänä toimintana. Kirjoittajat ottavat myös annettuna itse talouden käsitteen. Nähdäkseni taloutta koskevan filosofisen pohdinnan tulisi lähteä liikkeelle kysymällä, mitä talous on, miten talouden käsite voidaan ymmärtää ja millaisessa suhteessa se on muihin keskeisiin yhteiskuntafilosofisiin käsitteisiin. Talouden käsite kun ei ole täysin selvä asia historiallisesti, eikä nykyhetkessäkään. Taloudellisen toiminnan muotoja on lukemattomia ja talousjärjestelmiä on yhtä lailla useampia kuin yksi. Kirjan artikkeleissa tätä asiaa kyllä käsitellään sivuten, mutta varsinaisesti itse talouden käsitteen filosofinen analyysi jää tältä osin suppeaksi. Juuri tässä yleisessä talouden filosofisen kysymyksen erittelyssä olisi erilaisten filosofisten traditioiden esittely ollut mielenkiintoista ja samalla mukaan olisi voinut tuoda enemmän talouden kieleen liittyvää pohdintaa.

FILOSOFISIA KYSYMYKSIÄ

TALOUSTIETEESTÄ

Kirja on jaettu kahteen varsinaiseen osaan. Molemmat niistä on nimetty yleisesti. Ensimmäinen osa tarkastelee "näkökulmia taloustieteeseen" ja toinen "markkinoita, ihmistä ja yhteiskuntaa". Molemmat sisältävät viisi artikkelia.

Näkökulmia taloustieteeseen -osio lähtee liikkeelle Jaakko Kianderin aikalaistilannetta selventävällä "Globaali finanssikriisi, talouspolitiikka ja taloustieteen todellisuuskäsitys" -artikkelilla. Artikkeli on katsaus finanssi- ja 
eurokriisin syihin. Mitään järisyttävän uutta Kiander ei esitä, vaan hän pysyttelee varsin yleisellä taloustieteellisellä tasolla. Kriisin syiksi mainitaan esimerkiksi matalien korkojen ja nousevien (asuntojen) hintojen synnyttämä velkakupla. Eurokriisin hän näkee seuraavan pääasiassa finanssikriisistä ja toisaalta nimenomaan euron käyttöönotosta. Jälkimmäinen mahdollisti entisten heikon valuutan maiden (esim. Etelä-Eurooppa) matalan korkotason, mikä rohkaisi velkaantumista. Eurooppa jakautui ennen eurokriisiä hyvän ja huonon kilpailukyvyn maihin, mikä edisti epätasapainoa. Maksutaseen epätasapainoa on vaikea korjata ilman omaa valuuttaa, joka mahdollistaisi devalvoinnin. Tämän seurauksena kriisimaiden valtionvelan tason tarkkailusta on tullut rahoitusmarkkinoiden silmätikku.

Kiander korostaa, että ongelmat olisivat olleet mahdollisesti näkyvissä jo etukäteen, mutta taloustieteen - etenkin uusklassisen taloustieteen - perusoletukset talouden toiminnasta olivat väärät. Yksityinen sektori on nähty rationaalisena, mikä luo vääränlaisen luottamuksen talouden itseään korjaavaan toimintaan. Kiander siis kertoo varsin lyhyesti ja maltillisesti, kuinka kriisien syynä ei suinkaan ollut ahneus tai sattumanvarainen järjestelmän romahdus, vaan tietyt riskit, joita ei otettu tarpeeksi vakavasti. Hän kuitenkin jättää selvittämättä, miksi näin ei tehty. Kapitalismiin ei artikkelissa kiinnitetä huomiota oikeastaan lainkaan. Nykyisen talousjärjestelmän analyysi on kuitenkin aina väistämättä myös kapitalismin analyysia.

Kianderin artikkelin mielenkiintoinen osuus päättyy tähän, sillä artikkelin loppuosassa hän esittelee - selkeästi ja tiivistäen - erilaisten 1900-luvun taloustieteellisten teorioiden näkemyksiä. Rivien välistä Kianderin artikkelista voi kenties lukea jonkinlaisen uusklassisen taloustieteen kritiikin ja jonkinlaisen keynesiläisyyden puolustuksen, mutta varsinaisesti Kiander ei, kuten eivät muutkaan kirjoittajat, ota kantaa kysymykseen, miten talous voitaisiin nähdä ja järjestää toisin.

Osion toisessa artikkelissa Jukka Gronow tarkastelee sitä, kuinka tieteelliset "ikätoverit" sosiologia ja taloustiede suhtautuvat talouden käsitteeseen. Gronow pohtii ennen kaikkea niin sanotun rajahyötyteorian asemaa ja kritiikkiä sosiologiassa. Rajahyötyteoria tai marginalismi olettaa, että tavaran hinta määräytyy siitä saatavan hyödyn mukaan. Modernilla aavikolla eli lentokentällä vesipullosta voidaan pyytää 3 euroa, mutta hanavetenä nautittu vesi on lähes ilmaista. Rajahyötyteoriaan liittyy myös mielihyvän periaate. Kun rationaalisuus ja mielihyväperiaate yhdistetään, saadaan aikaiseksi rationaalisesti omaa mielihyvää ja hyvinvointia tavoitteleva homo ceconomicus. Sosiologian perinteisen kritiikin kohteena on ollut tämä taloudellisen ihmisen malli, monestakin syystä.

Artikkelissaan Gronow esittelee Simmelin, Durkheimin ja Weberin suhdetta rajahyötyteoriaan. Näistä Weber saa suurimman huomion, mikä onkin perusteltua, sillä Weber vaikutti huomattavasti amerikkalaiseen sosiologiaan, muun muassa Parsonsiin ja Smelseriin. Parsonsin sosiologiassa taloudellisen toiminnan logiikka on merkittävässä asemassa, mutta sitä ei nähdä kaiken kattavana yhtenäisenä ja yksinkertaisena logiikkana (siis juuri bomo ceconomicuksen toimintana). Sen sijaan toiminnan taloudellinen logiikka (yksinkertaistetusti markkinat) saa eri muotoja riippuen erilaisista sosiaalisista järjestelmistä, joissa se toteutuu.

Gronow toistaa lopussa Kianderinkin esittämän ajatuksen, jonka mukaan taloustiede ei ole sinänsä "todellisuustiede" eikä se perustu täysin pitävään empiiriseen todistusaineistoon ja tutkimukseen kuten sosiologia. Sosiologian tavoitteena ei myöskään ole yleisesti voiton maksimointi tai mahdollisimman suuren yhteiskunnallisen tai poliittisen vallan tavoittelu, vaikka näihinkin tarkoituksiin sitä usein käytetään. Taloustieteen ja sosiologian intressit ovat erilaiset, mistä johtuen näiden kahden tieteenalan on vaikea löytää perimmäistä yhteistä säveltä - mikä on varmasti hyvä asia. Yhteiskuntien ohjauksessa ja suunnittelussa toivoisi kuitenkin nykyisin enemmän painoarvoa kriittisen sosiologian näkemyksille 
kuin yltiöpositivistisen taloustieteen tekemille rationaalisuus-olettamuksille.

Kolmannessa artikkelissa Jaakko Kuorikoski ja Aki Lehtinen käsittelevät markkinatasapainoa ja markkinamekanismia. Tasapainon käsite on tunnetusti yksi modernin taloustieteen ja etenkin uusklassisen ajattelun keskeisimmistä käsitteistä. Markkinoiden ajatellaan "luonnostaan" pyrkivän kysynnän ja tarjonnan tasapainoon. Äärimmäisessä mallissa kaikki yhteiskunnan ja ihmisten välinen toiminta nähdään rationaalisena markkinakäyttäytymisenä. Tästä voidaan päätyä oletuksiin siitä, kuinka markkinoita ei tulisi häiritä keinotekoisilla rajoituksilla tai ohjauksella.

Kuorikoksi ja Lehtinen tyytyvät esittelemään asiaa tieteenfilosofisesta näkökulmasta, vaikka mielestäni olennainen kysymys on poliittisen filosofian alaa. On nimittäin naiivia ajatella (Kuorikoski ja Lehtinen eivät näin tee), että ihmisten rakentama talous toimisi jotenkin "luonnollisesti" tasapainoon hakeutuen. Tämän todistaa historia, ja on myös selvää, että valtion sääntelyn vastustaminen on tiettyyn poliittiseen ideologiaan kuuluvaa vaikuttamista. Siksi tasapainoteorioita kohtaan tulisi siis esittää muutakin kuin tieteenfilosofista kritiikkiä. Vapaita ja luonnollisia markkinoita ei kerta kaikkiaan ole olemassa, eivätkä ne koskaan ole mahdollisia. Kuorikosken ja Lehtisen artikkeli on kuitenkin hyvä yleisesitys aiheesta ja he korostavat tekstin lopussa, kuinka taloudellista toimintaa tulee lähestyä tutkimalla markkinamekanismia (ihmisten välistä vuorovaikutusta), ei lähtien liikkeelle joistain enemmän ja vähemmän absurdeista oletuksista koskien ihmisluontoa.

Kirjan järjestyksessä viides artikkeli, Risto Vilkon "Matemaattisen taloustieteen alkulähteillä" liittyy monin tavoin Kuorikosken ja Lehtisen artikkeliin. Artikkelissaan Vilkko esittelee 1800-luvulla syntynyttä matemaattista taloustiedettä. Vilkon artikkelin anti onkin suurelle yleisölle nykyisin varsin tuntemattomien teoreetikkojen esittely. Hän käy läpi useiden varhaisten taloustieteilijöiden ( $\mathrm{mm}$.
Cournot, Walras, Jevons, Marshall) teorioita osoittaen, vaikkakaan ei eksplisiittisesti mainiten, että taloustiedekin on - ei suinkaan Jumalan sanaa - vaan ihmisten rakentama tietämisen ja poliittisen vaikuttamisen toimintamuoto. Tämä esitys on myös hyvä taustoitus nykyiselle taloustieteelle, joka edelleen uskoo matemaattisiin malleihin. Esimerkiksi vuoden 2008 kriisin jälkeen Ranskassa nousi iso kohu merkittävästä taloustieteellisestä palkinnosta, joka myönnettiin juuri ennen kriisiä matemaattisen taloustieteen edustajille. $\mathrm{He}$ joutuivat toteamaan heti kriisin jälkeen yksioikoisesti, että heidän laskelmansa eivät kerta kaikkiaan pitäneet paikkaansa.

Ensimmäisen osan järjestyksessä neljäs artikkeli käsittelee taloutta aivan toisesta näkökulmasta. Jussi Kotkavirran artikkeli alkaa lainauksella Kari Hotakaisen Jumalan sana -romaanista. Kuten Kotkavirta artikkelissaan hienosti Hotakaisen ajatusta jatkaen argumentoi, "markkinat" eivät suinkaan käyttäydy kuten rationaalisesti toimiva aikuinen, vaan kuten tunnemyllerryksessä pyörivä teini. Markkinoiden toiminta vaikuttaa myös harvinaisen maskuliiniselta, sillä markkina- ja talouspuheeseen liittyy paljon uhoamista ja kiukuttelua. Nämä vertaukset sopivat hyvin yleisempään kuvaan, jossa markkinamiesten ja talouspamppujen uholle vastakkaisiksi diskursseiksi asettuvat usein hieman lässyttävät ja surumieliset puheet kaiken hyvän katoamisesta ja jokaisen pienen ihmisen ihmisarvosta.

Kotkavirran artikkeli on miellyttävä poikkeus kirjan tarjonnassa. Kotkavirta kirjoittaa, kuinka asiantuntijoiden esittämä talouden metafysiikka on latteaa ja käytännöllistä, varovaista, asiallista ja analyyttista. Samaa voisi sanoa monista kirjan artikkeleista, jotka tavallaan vain toistavat, ehkä hieman avaten, talouskeskustelun tylsää itseymmärrystä. Kotkavirta nostaa kuitenkin esille sen, kuinka ihmisille talouden muutokset liittyvät yleensä epävarmuuteen, pelkoon, kateuteen tai vaikkapa huoleen.

Artikkelissaan Kotkavirta erittelee yleisimpiä nykyisiä tunneteorioita ja pohtii niiden 
suhdetta talouteen. Jälleen kritiikin kohteeksi nousee rationaalinen bomo ceconomicus. Martha Nussbaumin ja Antonio Damasion tunneteorioiden lisäksi Kotkavirta nostaa esiin myös psykoanalyyttisen käsitteistön, jonka avulla taloutta voitaisiin analysoida. Hän korostaa, kuinka taloudellisessa toiminnassa on havaittavissa paljon erilaisia pakenemisen, välttämisen ja vetäytymisen ilmiöitä. Tuckettiin ja Taffleriin viitaten Kotkavirta esittää, kuinka rahoitusmarkkinoilla toteutuu myös erilaisten "fantastisten objektien" ilmiö: ihmiset rakentavat finanssitoimintaan erilaisia mielen luomuksia, joihin he voivat projisoida tunteita, toiveita ja fantasioita, kuitenkin samalla kadottaen suhteen todellisuuden lainalaisuuksiin.

Kotkavirran näkemyksen mukaan rahoituskriisit ja vastaavat eivät suinkaan johdu vain pelkistä rakenne- ja säätelyvioista, vaan myös rahoitusmarkkinoiden miltei hypnoottisesta taloudesta, joka houkuttelee ihmisiä ympärilleen kuin mesi ampiaisia. Kaikki taloudellinen toiminta ei siis ole rationaalista ja tiedostettua toimintaa - seikka, jonka fantastisia rahoitusinstrumentteja tarjoavat johdannaismyyntimiehet kenties tajuavat erittäin hyvin.

VIELÄ KERRAN HOMO ๔ECONOMICUS

Kirjan toisessa osassa kirjoittajat tarkastelevat asioita, jotka uppoavat yleisotsikon "Markkinat, ihminen ja yhteiskunta" alle. Kuten ensimmäisessäkin osassa, artikkelit liittyvät vain väljästi toisiinsa. Toisaalta myös näitä artikkeleita vaivaa helpohko homo ceconomicuksen kritiikki, joka on suurin piirtein yhtä vanhaa kuin itse tarina kuuluisasta taloudellisesta ihmisestä.

Osion kolmessa ensimmäisessä luvussa liikutaan erityisesti markkinoilla. Uskali Mäki tarkastelee artikkelissaan universaalin talousontologian perusperiaatteita. Mäki kysyy, mistä maailma on tehty ja esittää hypoteettisen vastauksen, jonka mukaan maailma on tehty markkinoista. Hän esittää, että markkinoiden merkitys niin puheessa kuin ihmisten kanssa- käymistä välittävänä toimintana on lisääntymässä. Markkinaistuminen on siis hänen mukaansa käynnissä oleva suuri muutosprosessi, josta seuraa markkinaontologia, markkinaetiikka ja niin edelleen.

Mäen artikkelin ongelmana onkin sen varsin yleinen taso: se oikeastaan vain luettelee jokaisen kaduntallaajan huomioita maailmasta ja keskusteluista. Ei ole myöskään kovin yllättävää ilmoittaa, että "markkinaistuminen etenee paitsi reaalimaailmassa myös sitä koskevassa ajattelussa ja puheessa" (s. 109). Myöskään erilaiset luettelot kaikista niistä alueista, joilla markkinoistuminen etenee, eivät tule varmaankaan yllätyksenä kellekään.

Mäki esittää lopuksi provokaation, jonka mukaan taloustieteen filosofiasta on tullut filosofian tärkeimpiä osa-alueita. Miksi? Koska talous ja talouspuhe hallitsevat nykyistä kulttuuriamme. Selitys on liian yksinkertainen jättäessään pois kaikki poliittisen ja ideologisen vallan ulottuvuudet. Mäki peräänkuuluttaa myös systemaattista tutkimusta aiheesta, mutta hänen artikkelinsa soveltuu paremmin esimerkiksi yläkoulun taloustiedon tunnille kuin systemaattisen talousfilosofian tutkimusavaukseksi. Suomalaisessa ja kansainvälisessäkin mittakaavassa aiheesta lähes käsittämättömän paljon julkaisseelta professorilta olisin odottanut hieman täsmällisempää tekstiä.

Osion toisessa luvussa Eerik Lagerzpetz esittelee ja käsittelee Marxin ja Hayekin näkökulmia markkinakapitalismiin. Tällaisena vertailevana tekstinä artikkeli on kirjan ainoa ja siksi varsin tervetullut. Se on myös ainoa artikkeli, jossa Marxin teoriaa käsitellään vakavissaan - vaikka Lagerspetz väittää mielestäni hieman liian kevein perustein, että”...Marxin arvoteoria on lopullisesti kuopattu. Jokainen yritys pelastaa se johtaa kummallisiin käsitteellisiin kiemuroihin, eikä liioin ole helppo nähdä, mitä sen avulla voisi selittää paremmin kuin muilla taloudellisen arvon teorioilla." (S. 127.) Maailmalla - ja myös Suomessa - Marxin arvoteoriaa tutkitaan kuitenkin edelleen runsaasti. Vaikka se onkin monilta osin ongel- 
mallinen suhteessa nykypäivän talouteen, on siinä kuitenkin elementtejä, jotka ovat edelleen huomionarvoisia. Vaikka arvo ei varmastikaan muodostu kokonaan ja ainoastaan työstä, on käytetyllä työajalla kuitenkin merkittävä rooli työstä irti revittävien voittojen muotoutumisessa - miksi muuten kukaan etsisi halvempia tuotantokustannuksia ja haluaisi systemaattisesti laskea työvoiman hintaa.

Lagerspetzin artikkeli on kirjan ehdotonta parhaimmistoa selkeytensä ja informatiivisuutensa vuoksi. Marxin ja Hayekin tuotantoja ei myöskään lukaista yhdessä iltapäivässä. Onkin hienoa, että professori on tarttunut näin isoon teemaan tutkimuksessaan. Tämän artikkelin perushuomio on, että se mikä on Marxille vieraantumista, on Hayekille vapauden ehto. Tämän huomion pohjalle voisi kenties rakentaa laajempaakin tutkimuksellista orientaatiota.

Kaksi seuraavaa artikkelia, Kristiina Rolinin "Onko voiton maksimointi moraalisesti oikeutettua" ja Jukka Mäkisen sekä Arno Kourulan "Yritysvastuun yhteiskuntafilosofiaa" käsittelevät molemmat yritysten ja markkinoiden toimintaa etiikan ja oikeudenmukaisuuden näkökulmasta. Rolinin artikkeli keskittyy ruotimaan erityisesti uusliberalismin teoreetikon Milton Friedmanin vuonna 1970 julkaistua artikkelia, jossa hän argumentoi, että yritysjohtajan moraalinen velvollisuus on voiton maksimointi, koska yritysjohtaja on vastuussa nimenomaan yrityksen omistajille, ei yhteiskunnalle.

Rolin avaa kysymyksiä sopimusetiikan kautta: mikä sopimus menee toisen edelle? Onko esimerkiksi yritysjohtajan sopimus omistajien kanssa tärkeämpi kuin hänen tekemänsä "yhteiskuntasopimus" muiden ihmisten kanssa? Onko yrityksillä siis oikeus toimia siten kuin ne usein toimivat eli selvästi yleistä etua vastaan, omaa voittoa maksimoiden? Rolinin mukaan voiton maksimointi on moraalisesti hyväksyttävää, kunhan se tapahtuu niissä rajoissa, jotka yleiset moraaliset velvollisuudet asettavat. Rolin korostaa, että voiton maksimointia eivät rajoita siis ainoastaan paikalliset lait ja tavat, vaan hänen mukaansa "etiikka yli- päänsä ei ole sellainen asia, joka kuuluu pelkästään kullekin kulttuurille tai yhteiskunnalle ominaisten 'tapojen' piiriin" (s. 154). Tämä artikkelin päättävä lause on erittäin mielenkiintoinen, sillä asiahan on mitä ajankohtaisin ja poliittisin. Samalla se on myös poliittisesti ongelmallinen: kuka nimittäin määrittelee tällaisen universaalinen etiikan?

Mäkinen ja Kourula käsittelevät artikkelissaan pitkälle samaa asiaa kuin Rolin. He huomauttavat osuvasti, että "globalisaatioprosessin myötä liikeyrityksistä on kuitenkin tullut yhä merkittävämpiä poliittisia toimijoita” (s. 155). Vaikka ei ole mikään suuri keksintö kertoa, että talous ei ole käytännöllinen, arvoneutraali tai epäpoliittinen tapa hoitaa yhteiskunnan tavarantuotantoa ja jakelua, on tämän kertaaminen nykyaikana tarpeellista. Kuten kirjoittajat huomauttavat, kylmän sodan päättymisen jälkeen talouskeskustelua on käyty jokseenkin epäpoliittista lähtökohdista käsin.

Artikkelissaan kirjoittajat nojautuvat Suomessakin kohtuullisen vahvan jalansijan saaneen John Rawlsin teoriaan. Rawls on tietenkin kansainvälisesti yksi viitatuimpia yhteiskuntafilosofeja ja yksi anglo-amerikkalaisen yhteiskuntafilosofian suurimmista nimistä. Kirjoittajat eivät kritisoi Rawlsin teoriaa, vaan esittelevät sen keskeisiä näkemyksiä. Artikkelin loppupuolella kirjoittajat korostavat "politiikan paluuta" ja poliittisen yritysvastuun käsitettä, jota ovat kehittäneet muun muassa Andreas Scherer ja Guido Palazzo. Myös tämä suuntaus korostaa, että nykymaailmassa politiikan ja talouden välinen erottelu ei ole enää pätevä. Tässäkään ei sinänsä ole varsinaisesti mitään uutta, mutta näkemyksellä on monia seurauksia, jos se otetaan vakavasti. Se voi hyvinkin johtaa ajatukseen, jonka mukaan liikeyritysten politisoituminen on hyväksyttävää. Yhtä lailla se voi johtaa poliittisten vastuiden yksityistämiseen. Tällainen kehitys ei vaikuta kovinkaan mielekkäältä, vaikkakin varsin mahdolliselta.

Kirjan viimeisessä varsinaisessa luvussa Tarja Knuutila käsittelee kaupallistuneen tieteen normeja. Kirjoitus on oikeastaan puheenvuoro 
yliopistojen ja tieteen uusiin taloudellisiin paineisiin ja vaatimuksiin. Knuutila esittelee tekstissään aluksi Robert Mertonin klassisia tieteen normeja ja käsittelee sitten näiden normien toteutumista erään suomalaisen yliopiston kieliteknologisen tutkimusyksikön tekemän tutkimuksen tuotteistamisen kautta. Tämä empiirinen kuvaus käytännössä tapahtuvasta tieteen tuotteistamisesta on tervetullut. Olisikin suotavaa, että tämän tekstin huomaisivat monet yliopistojen uudesta tiedepolitiikasta kiinnostuneet lukijat, eikä se hukkuisi väärän "kontekstin" vuoksi tämän kirjan uumeniin.

Kirja päättyy teoksen yhden toimittajan, Ilkka Niiniluodon epilogiin, joka kysyy, saako rahalla onnea. Teksti on varsin yleisluontoinen, kuten johdantokin, jonka teemoja se osittain jatkaa ja kertaa. Epilogi toistaa monia sellaisia "maalaisjärjen" mukaisia sovinnaiskäsityksiä, joita tämän tason kirjoista ei mielellään lukisi. On esimerkiksi varsin suosittua hokea, että Berliinin muurin murtuminen ja Neuvostoliiton romahtaminen osoittivat, kuinka suunnitelmatalous epäonnistui "ihmisen onnellisuuden toteuttamisessa". Nykyisen ekologisen katastrofin aikakaudella olisi ehkä syytä kysyä pikemminkin, voisiko suunnitelmatalous estää ihmiskuntaa tuhoamasta koko maapalloa ja ihmisiä siinä samalla. Suunnitelmataloutta ei mielestäni voi siis yksinkertaisesti todeta epäonnistuneeksi, koska se ei toiminut Neuvostoliitossa. Lisäksi esimerkiksi nykypäivän Kiinan talous perustuu hyvin tarkkaan suunnitteluun ja on selvää, että Kiina on ollut eittämätön taloudellinen menestys.

Niiniluoto ottaa tekstissään kantaa myös joihinkin aikalaiskeskusteluihin, mutta hänen kielensä on valitettavasti tällä kertaa niin keskellä suuta, ettei hän saa sanotuksi oikeastaan mitään. Toki Niiniluoto sitoutuu talouskasvuun ja tyrmää esimerkiksi degrowth-keskustelun suoralta kädeltä. Niiniluodon mukaan talouskasvu tuottaa hyvinvointia. Marxia seuraten voisi tähän sanoa vastaan, että talouskasvu tuottaa kyllä ennätysmäään rikkautta maailmaan, mutta samalla myös ennätysmäärän köyhyyttä. Kukaan maailman väestöräjähdystä ja samanaikaista kapitalismin kasvua viimeiset kymmenet vuodet seurannut ei voi väittää tätä seikkaa vastaan. Niiniluoto puhuukin erittäin länsimaisesta ja hyvinvointivaltiokeskeisestä perspektiivistä.

Niiniluoto seurailee eräänlaista aristotelisen realismin periaatetta: onnen mittari ja lähde ei voi olla talous, mutta ilman vaurautta ihmiset eivät voi olla todella onnellisia. Olisi kuitenkin suhtauduttava erittäin kriittisesti kaikkiin subjektiivista onnentunnetta tai -kokemusta mittaaviin mittareihin. Ihminen kun voi tyytyä vähään, joskus jopa olemattomaan. Siksi Niiniluoto korostaakin ansiokkaasti artikkelinsa lopussa, kuinka arvokkaiden ja mielekkäiden asioiden toteutuminen on tärkeämpää kuin subjektiivinen tyytyväisyyden tunne. Kirja päättyy siis kehotukseen jatkaa keskustelua filosofien, talousmiesten, poliittisten päättäjien ja kansalaisten välillä yhteiskunnan arvoista, jotta voimme nostaa arvokkaiksi muitakin asioita kuin talouden kasvun ja kukoistuksen.

LISÄÄ JA PAREMMIN

Talous ja filosofia on monella tapaa mielenkiintoinen teos. Sitä ei kuitenkaan voida missään nimessä pitää kattavana tai tyhjentävänä - päinvastoin. Olisi mielenkiintoista esimerkiksi kiinnittää huomiota siihen hiljaisuuteen, joka filosofien ja yhteiskuntatieteilijöiden piirissä on vallinnut aina $1980-1 u-$ vulta lähtien ja kysyä, miksi taloutta ei ole käsitelty enemmän filosofisesti? Sama koskee vaihtoehtoisia talouden muotoja ja Marxin perintöä talousfilosofialle: miksi tämäkään kirja ei näe mitään vaihtoehtoa vallitsevalle markkinataloudelle. Marxilaisuuden haamuja pelätään selvästi edelleen, eikä taloutta osata lähestyä oikein rennoin ottein ja aidosti kysyvällä tavalla.

\section{- MIKKO JAKONEN}

